\title{
Spotlight-Interview with Mark Somos
}

\author{
Raphael Schäfer \\ Max Planck Institute for Comparative Public Law and International Law, \\ Heidelberg, Germany \\ schaefer@mpil.de \\ Maren Körsmeier \\ Editorial Assistent, Student of Law, Ruprecht Karls University Heidelberg, \\ Heidelberg, Germany \\ koersmeier@mpil.de
}

The Journal of the History of International Law is delighted to present a new format aimed to offer new opportunities for open access publishing: the annual spotlight article. This format highlights original contributions from younger scholars that widen our understanding of international law and its history by inter alia providing new perspectives, offering new methods and questioning traditional narratives. For each of JHIL's upcoming volumes, the editorial board will select one 'Spotlight' article, for which our publisher Brill will provide unlimited open access.

JHIL's editorial board chose as its inaugural 2019 Spotlight, the article 'A New Architecture of Justice: Dan Kiley's Design for the Nuremberg Trials' by Mark Somos and Morgan Gostwyck-Lewis (Journal of the History of International Law 21(1) (2019), 104-139). In the following interview, we take a closer look at the article 'under the spotlight', the motivations of its authors and the research carried out. The interview was conducted by the managing editor of the JHIL, Raphael Schäfer, and JHIL's student assistant, Maren Körsmeier, with the first author, Mark Somos, the second author being unavailable.

JHIL: Mark, congratulations to you and Morgan to be JHIL's inaugural spotlight article and heartfelt thanks for telling us more about it! How did the two of your come across this fascinating topic?

Mark Somos (MS): Thank you very much!

It was a happy accident in multidisciplinarity. When I started my $\mathrm{PhD}$ at Harvard in 200o, I resolved to graduate without student debt. Most student 
jobs offered $\$ 10$ an hour, except for a research assistant post in eighteenthcentury French landscape architecture at the Graduate School of Design with a wonderful professor called Joseph Disponzio, who offered $\$ 15$. As we worked on Jean-Marie Morel (1728-1810), a fascinating Enlightenment landscape designer, I told Joe about my interest in international criminal law. Joe told me that Roxbury, the part of Boston where I lived at the time, was the birthplace of Dan Kiley, one of the most influential American landscape architects and still alive at the time (Kiley died in 2004). Joe also mentioned, as a then little-known fact, that Kiley was in charge of restoring the Nuremberg Palace of Justice, and that his papers are now in the Graduate School's archive.

Though I knew nothing about architecture, Joe's story resonated with me as my mother designed hospitals and I grew up in a flat often covered in blueprints. I kept thinking about Kiley and Nuremberg and continued to collect relevant materials while I worked on other topics. Seventeen years later, I was at the British School at Rome, designed to encourage multidisciplinary work, and I met Morgan, a brilliant architect with an interest in history. Together we could figure out aspects of the story that made sense only from a multidisciplinary perspective. I think even classic interdisciplinarity, focusing on intersections and links between disciplines, would not have been enough to tell Kiley's story right. Morgan and I were both trained in a fairly rigorous setting, with no classes, for instance, introducing us to each other's respective fields; but in Rome we were luckily thrown together in a way that allowed us to not only find a shared interest, but also to learn each other's professional vocabulary and sensibilities. We talked, walked, and drew at the British School for three happy months, ready to start writing after my return to Harvard for a closer look at Kiley's papers.

JHIL: In the acknowledgements section you mention an article you wrote in the past that dealt with the legitimacy of the International Military Tribunal and Kiley's design of Courtroom 6oo but did not include mentions of the original drawings of Kiley found in the Harvard archives. Did the finding of Kiley's original plans pose any challenge to you, to correct any assumptions made in your first article, and did it change your view on the architectural questions bound to the IMT? Did you have other motivations to write the article?

MS: Kiley subverted the traditions of courtroom architecture by placing a screen and the public at the opposite ends of Courtroom 6oo's main axis, and prosecution and judges, and defendants and their attorneys across the room's narrower span. When I first learnt this, I found the symbolism of Kiley letting 
the facts speak for themselves on the screen and turning the global public into the judge inescapable. In 2002, I published an essay about that symbolism in relation to the then ongoing trial of Slobodan Milošević and the anticipated trial of Saddam Hussein. The essay focused on the appeal to humanity as the ultimate judge and source of both political and legal authority. Kiley's design served merely as a rhetorical hook then. The reason was partly that without his original plans and without the skills to reconstruct his process, I could not establish whether he subverted traditional courtroom architecture knowingly, or whether he did it chiefly due to the practicalities of the reconstruction. When fifteen years later Morgan and I realised that Kiley knew exactly what he was doing, and we understood the level of detail to which Kiley controlled the courtroom's design, the story became more than a rhetorical ornament.

JHIL: How did Dan Kiley, a landscape architect, come to be the designer of the courtroom of the Nuremberg Trials? Can you explain why over 70 years after the Nuremberg Trials we still know so little about this important decision by the United Nations War Crimes Commission and, especially, why Kiley's original plans were never published or do not appear in any publication related to him?

MS: I used to think that Kiley happened to be the most qualified officer available for the task, but our research for JHIL uncovered a deeper connection. Kiley was Chief of Design in the Presentation Branch of the Office of Strategic Services, predecessor of the CIA. The oss developed its own extraordinary set of visual techniques for conveying and curating information. President Truman abolished the oss while Kiley was working in Nuremberg. I think further research in oss archives will shed more light on the conceptual and practical tool kit that Kiley applied to the Nuremberg Trials not only as a cinematic, but also as an architectural event.

I cannot explain why we still know so little about the Nuremberg Trials. It was a complex and large-scale undertaking, and it has attracted a great deal of scholarly attention, but there is a lot still left to do. For instance, I would love to know more about the discussions and reflections on the гмт that presumably took place before Kiley's courtroom disappeared in 1961 (coincidentally the year of Eichmann's trial in Jerusalem), when the Bavarian judiciary regained control and restored Courtroom 600 to its traditional format. In any case, the relative dearth of multidisciplinary research in law and architecture may be another reason; Kiley's Nuremberg designs are missing even from his Collected Works. 
JHIL: In your understanding, was Kiley's design for the Nuremberg Trials peculiar or does it stand in a general 'tradition' of his overall work?

MS: As far as I know, Kiley's Nuremberg design is completely sui generis in both courtroom architecture and in his own oeuvre which, with this one exception, is devoted to landscape architecture.

JHIL: In your article you state that 'it seems to have been Kiley's decision to radically break with accepted conventions' (p. 117). Would a 'traditional' courtroom have been inappropriate because it would have relativised the historic singularity and atrocity of the crimes prosecuted in the trials? You also argue that the IMT was able 'to project the principle that no individual, regardless of rank, was above an international, even supranational, definition of justice' and represented 'a remarkable episode where the reimagining of international law went hand in hand with a transformation in the spatial manifestation of justice' (p. 1). Was Kiley's architecture a catalyst for this transformation or rather a side effect?

MS:These are important questions well worth asking, and I cannot fully answer them. A traditional courtroom might have been appropriate, but we know that Kiley was excited about turning the screen - public relationship into the dominant one; while Justice Robert Jackson relished the dramatic opportunities afforded by placing defendants and judges face-to-face. It is an interesting counterfactual to speculate how our understanding and iconography of the Nuremberg Trials would be different without Kiley's break from tradition.

Kiley's design is transformative in that screens have become accepted elements of courtrooms, and the principle of the international rule of law remains memorably embedded in familiar images of the Nuremberg courtroom. It is difficult to determine whether his design was a catalyst or a side effect of this transformation. One might argue that the evidence we presented in JHIL shows how the appeal to the public and to a reimagined, physically embodied principle of justice intentionally worked in harmony in the prosecutorial speeches and in the courtroom design. Whether catalyst or side effect, the spatial arrangement worked alongside and gave physical form to this evolution of international criminal law.

JHIL: What is the reason that some scholarly works attribute the design of Courtroom 600 to Chief prosecutor Jackson rather than to Dan Kiley, who, as you state in the article, rightfully claims the authorship? 
MS: It is seldom smart to speculate about the reasons for lacunae or possible mistakes in prior scholarship, especially when the primary sources are clear that Kiley did, and Jackson did not, claim authorship and responsibility for the design. Two reasons for what I think is a mistaken attribution to Jackson might be the harmony between Jackson's speeches and the courtroom layout, and the prima facia improbability of Kiley's acute alertness to the judicial significance of his design. This alertness seems improbable if you look at only Kiley's education and later career. However, the sources we discuss in the JHIL article prove that he had it.

JHIL: Architecture and international law is a truly fascinating topic. Where else do you see unique architectural manifestations of a peculiar international thought? Where do you think archival multidisciplinary research might provide new insights for our field? Do we already have detailed knowledge of the architectural history of the Peace Palace?

MS: I just finished a paper, forthcoming in a collection this year, on houses without cities. There is a long-running and I think unfortunately forgotten body of thought about the household as an adaptable, potentially selfsufficient unit that works with the state or international community when the state or international community functions, but which defends and sustains itself when the state or international community fails. From Atra-Hasis and Utnapishtim in 4,ooo-year-old Akkadian tablets, and Noah in the Bible, we have had stories about escapes from cataclysms caused by overpopulation, feuds or impiety. Xenophon, Philodemus, Columella, Leon Battista Alberti, Shakespeare and J. Hector St. John de Crèvecœur have all described households that have very specific, highly defined architectural and organisational features that render them resistant to crises, and able to reengage conventional political spaces and relationships in post-crisis renewal. They can produce their own food, defense and population, but always remain semi-permeable toward national and international communities. I would not have been alert to the architectural elements in these texts (including Shakespeare's) without writing for JHIL, and the excellent reviewing and feedback process.

I would love to do more research on the architectural history of the Peace Palace! I have looked at the 216 designs that were proposed, including Louis Cordonnier's, which was eventually simplified to create the final plan. I have also done some archival work on Andrew Carnegie which suggests that a great deal of (I think) interesting material remains undiscussed in the 
existing literature. There is definitely a project for an architect and a legal historian there.

Finally, it is wonderful to see our JHIL article cited in a range of publications and $\mathrm{PhDs}$ over the last year alone. We are very grateful to JHIL, to the readers, and to those who develop our limited original claim into broader insights into international legal history and the potentials of multidisciplinary research, despite the steep learning curve needed to connect, in this case, architecture and law. 